\title{
Effect of fluoride release on the polished surface after polishing with a bur containing fluoride
}

\author{
In-Sun Jeong ${ }^{1}$, Hong-Won Kang ${ }^{2}$, and Kwi-Dug Yun ${ }^{3 *}$ \\ ${ }^{1}$ Ph.D. Student, Interdisciplinary Program of Biomedical Engineering, Chonnam National University Graduate School, Gwangju, Republic of Korea \\ ${ }^{2} \mathrm{CEO}$, Denbio Co., Ltd., Gwangju, Republic of Korea \\ ${ }^{3}$ Professor, Department of Prosthodontics, School of Dentistry, Chonnam National University, Gwangju, Republic of Korea
}

This study aimed to evaluate the fluoride release amount on the polished surface after polishing with a bur containing fluoride. The point-shape dental burs and disk-shape specimens containing 1,450 ppm fluoride were fabricated. The fluoride released on the dental bur was measured after 1, 3, 7, and 9 days from the disk-shaped specimens $(n=5)$. The point shape dental bur polished the conventional composite resin surface 5 times during 5 seconds at 3,000 rpm. The polished composite resin surface was measured the fluoride release amount after 1, 3, 7, and 9 days. IBM SPSS Statistics ver. 25.0 (IBM Corp., Armonk, NY, USA) was used for statistical analysis. The dental bur containing fluoride were released at $71.68 \pm 3.82 \mathrm{ppm}$ fluoride after 1 day, $75.52 \pm 2.19 \mathrm{ppm}$ after 3 days, $77.5 \pm 1.86 \mathrm{ppm}$ after 7 days, and $77.58 \pm 1.30 \mathrm{ppm}$ after 9 days. The polished surface with the point shape dental bur containing fluoride was released at $7.98 \pm 0.62 \mathrm{ppm}$ fluoride after 1 day, $8.48 \pm 0.65 \mathrm{ppm}$ after 3 day, $8.80 \pm 0.41 \mathrm{ppm}$ after 7 days, and $8.75 \pm 0.35 \mathrm{ppm}$ after 9 days. The application of dental bur containing $1,450 \mathrm{ppm}$ fluoride showed the possibility of preventing dental caries and exerting an antimicrobial effect.

Key Words: Dental polishing, Drug delivery systems, Fluorides

(ㄷ) This is an open-access article distributed under the terms of the Creative Commons Attribution Non-Commercial License (http://creativecommons.org/licenses/by-nc/4.0) which permits unrestricted noncommercial use, distribution, and reproduction in any medium, provided the original work is properly cited.

\section{Introduction}

치아우식증은 치과 질환 중 가장 호발하는 질환 중 하나이며, 치아우식증의 치료는 레진과 같은 수복재로 재건한다. 그러나 수복 치료를 받은 치아의 $75 \%$ 가 재수복을 필요로 하며[1], 그 중 이차 우식에 의한 수복물 실패가 매우 빈번한데, 아말감 치 료의 경우는 총 아말감 실패의 $72 \%$, 레진 치료의 경우는 $43 \%$ 에 달한다[2,3]. 수복 재료 중 글라스 아이오노머 시멘트는 저농도 의 불소이온을 유리하는 특성으로 인해 치아우식 치료와 동시 에 예방적 개념이 동시에 가능한 재료이다. 그러나 구강내 용해
도가 높은 편이며, 초기 물리적인 성질이 좋지 않고, 심미적인 요구도가 높아짐에 따라, 그 사용 빈도가 감소되는 추세이다[4]. 하지만 시대가 지나도 치아우식을 예방하는 것이 치료보다 더 효율적인 처치이며, 치과치료에서 최우선적으로 고려해야 할 사항이다.

불소는 치과 재료 및 구강 보건 분야에서 가장 많이 쓰이는 항균성 재료로서, 치아우식 병소의 발생과 진행을 막는 대표적 인 물질이다. 구강 내에서 불소는 미생물의 대사 작용을 억제하 고 치아우식 예방효과를 나타낸다[5,6]. 치아 표면에 침착된 불 소는 법랑질 치질과 결합하여 수산화인회석을 불화인회석으로

Received June 18, 2020; Revised August 25, 2020; Accepted August 26, 2020

${ }^{*}$ Corresponding author: Kwi-Dug Yun, Department of Prosthodontics, University, School of Dentistry, Chonnam National University, 33 Yongbong-ro, buk-gu, gwangju 61186, Republic of Korea.

Tel: +82-62-530-5631, Fax: +82-62-530-5639, E-mail: ykd@jnu.ac.kr

Copyright $\odot$ 2020, Oral Biology Research Institute 
바꾸어 법랑질의 내산성을 증가시키며, 치면세균막에서 형성된 산에 의한 탈회를 억제한다. 또한, 저농도의 불소이온은 타액 내 무기질 성분에 의해 탈회된 치아의 재광화를 촉진시킨다[5,6].

다양한 불소제재 중 한 가지인 불소 바니시는 1960년대에 소 개된 이후 세계적으로 널리 사용되는 전문가 국소도포 불소제 제로서 대표적인 치아우식 예방치료 중의 하나이다[7]. 불소 바 니시는 치아 법랑질 표면에 얇게 도포되어 치아 표면에 오랫동 안 부착되고 접촉시간을 증가시켜 치아우식 예방 효과를 나타 낸다. 도포되는 양은 $0.5 \mathrm{~mL}$ 정도로 적기 때문에 불소 섭취에 따른 부작용은 적으며, 치아우식 예방효과는 크고 진료실에서 비교적 간편하게 도포할 수 있다는 장점이 있어 치아우식 활성 도가 높은 환자에게 유용하게 활용이 되고 있는 불소제제이다 [8]. 하지만 이 치료는 추가로 치과 내원을 필요로 한다는 단점 이 있다. 그러므로 이 연구는 치아우식 치료와 동시에 예방 효과 를 얻을 수 있는 방법을 찾아보기 위해 치과 수복재가 아닌 연 마용 실리콘 포인트에 불소이온을 함유시켜 치아우식증의 치료 와 함께 예방효과도 동시에 얻을 수 있는지 확인하고자 한다. 또 한 한국의 치과 진료실의 현실에서 다회용으로 사용되는 연마 용 실리콘 포인트 자체가 불소가 지속적으로 방출이 된다면 치 과 치료 기구의 감염예방에 도움이 될 것으로 생각된다.

이번 연구는 $1,450 \mathrm{ppm}$ 의 불소를 치과용 연마용 실리콘 포 인트에 함유시켜 성형 제작하여 연마용 실리콘 포인트의 불소 방출량은 얼마나 되는지를 확인하였고, 이 치과용 연마용 실리 콘을 이용하여 일반 레진 시편을 연마시켰을 때 레진 연마면의 불소 방출량을 평가하는 것이다.

\section{Materials and Methods}

\section{불소를 함유한 치과 연마용 실리콘 포인트의 불소 방출량 실험}

불소의 치아우식 예방 효과나 항균 효과 등은 재료에 포함된 불소의 함유량보다는 방출된 불소의 양에 좌우된다. 그러므로 재료에 포함된 불소의 양이 얼마나 방출되는지 확인하는 실험 이 필요하다.

실험군은 $1,450 \mathrm{ppm}$ 의 불소를 혼합하여 실리콘 포인트 제 작 방법과 동일하게 하여 지름 $15 \mathrm{~mm}$, 두께 $1 \mathrm{~mm}$ 의 원형 디스 크 형태의 시편으로 제작하였다(Fig. 1) 불소 방출량 실험에 대
한 대조군은 불소이온을 포함하지 않는 일반 실리콘 포인트 재 료로 같은 디스크 형태의 시편을 만들었다. 바인딩 재료는 Urethane dimethacrylate (UDMA; Dong-a chemical, Yangsan, Korea)를 사용하였으며 연마재로는 White alumina oxide (100 mesh/99\%; Sigma-Aldrich, St. Louis, MO, USA)를 사용하였 다. 광경화제로는 Camphorquinone (97\%, Sigma-Aldrich), 촉 진제로 Ethyl-4-(dimethylamino) benzoate $(99 \% \leq$, Sigma-

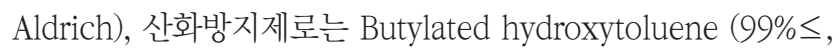
Sigma-Aldrich)을 사용하였다. 불소이온(F-)을 방출하는 원료 로는 NaF (Duksan chemical, Ansan, Korea)를 사용하였다. $1,450 \mathrm{ppm}$ 의 불소농도를 함유하기 위해 UDMA $398.5 \mathrm{~g}$, Alumina oxide 598 g, Camphorquinone 1 g, EDMAB 2 g, BHT $0.5 \mathrm{~g}, \mathrm{NaF} 3.205 \mathrm{~g}$ 을 planetary mixer (PL-5L; Uniongiyeon, Kimpo, Korea)를 이용하여 챔버온도 $60^{\circ} \mathrm{C}$, 진공압력 $0.1 \mathrm{bar}$ 의 조건으로 12 시간 교반하였다. 교반 후, 지름 $15 \mathrm{~mm} \times$ 두께 1 $\mathrm{mm}$ 의 홀이 가공된 acryl-mold (Jeil Acryl, Gwangju, Korea) 를 사용하여 $480 \mathrm{~nm}$ 의 광원파장을 가지고 있는 광경화기(Foshan jason medical apparatus Co., Guangdong, China)로 25 초간 조사하여 총 20 개의 시편을 제작하였다(Table 1).

불소 방출량 실험은 시멘트의 불소 방출량 방법을 참고하여

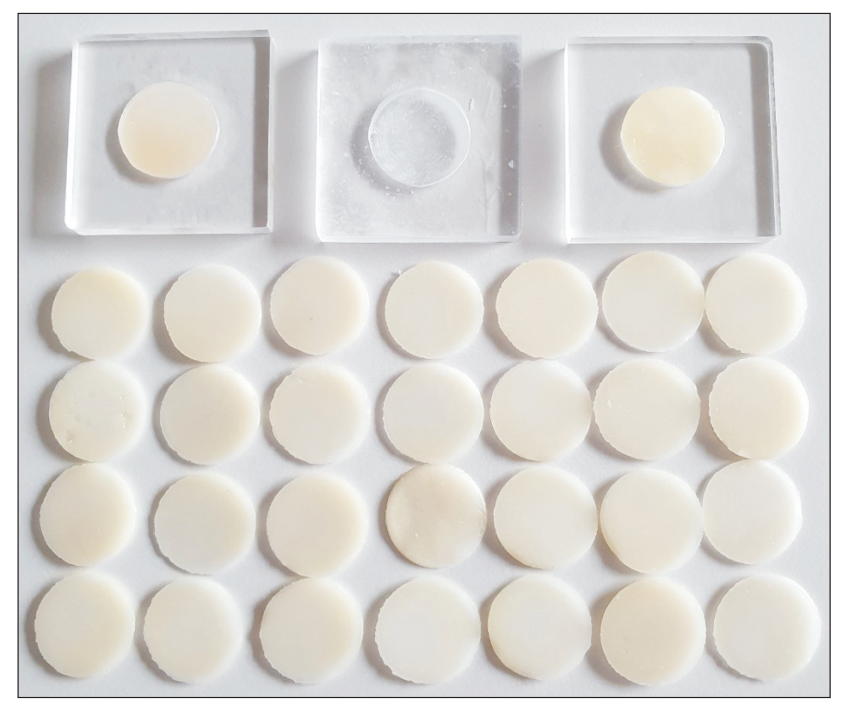

Fig. 1. A $15 \mathrm{~mm}$ diameter disk type specimen mixed with 1,450 ppm fluorine.

Table 1. Group explanation for fluoride releasement of the silicone point

\begin{tabular}{lcccc}
\hline \multicolumn{1}{c}{ Number of specimens } & $\mathbf{2 4} \mathbf{h}$ & $\mathbf{7 2 ~ h}$ & $\mathbf{1 6 8} \mathbf{h}$ & $\mathbf{2 1 6} \mathbf{h}$ \\
\hline Conventional silicone point & 5 & 5 & 5 & 5 \\
Silicone point with 1,450 ppm fluoride ion & 5 & 5 & 5 & 5 \\
\hline
\end{tabular}


시행하였다. 시편의 무게를 측정하고 지름 5 곳을 측정하여 평 균 지름을 계산하고, 시편의 중심부와 균일한 간격으로 떨어 진 주변부 4곳의 두께를 측정하여 평균 두께를 계산하여 표면 적 $(\mathrm{cm} 2)$ 을 계산하였다. $10 \mathrm{~mL}$ 의 탈이온수(DIWater; Koreacleanup, Suwon, Korea)가 담긴 플라스틱 용기에 시편을 각 각 침지하고, $37^{\circ} \mathrm{C}$ 드라이오븐에 1 일(24시간), 3 일(72시간), 7 일(168시간), 9일(216시간) 동안 5개의 시편씩 보관 후 시편을 제거하고, 피펫으로 검액 $1 \mathrm{~mL}$ 을 채취하여 탈이온수 $9 \mathrm{~mL}$ 를 더하고 완전히 혼합하여 불소이온 측정 시험용액을 만든다. 시 험용액에 TISAB buffer solution $10 \mathrm{~mL}$ (TISAB II; Thermo, Waltham, MA, USA)을 첨가하고, 불소미터(TiN-5101; Toko, Tokyo, Japan)를 이용하여 각각의 시험용액에 대한 불소농도를 측정한다. 시험용액에서 측정한 값으로부터 검액의 불소농도를 계산하여 불소 방출량을 아래 식과 같이 계산한다.

불소 방출량 $\left(\mu \mathrm{g} / \mathrm{cm}^{2}\right)=($ 검액의 불소농도 $[\mu \mathrm{g} / \mathrm{mL}] \times$ 검액의 양 $[10 \mathrm{~mL}]) /$ 표면적 $\left(\mathrm{cm}^{2}\right)$

불소방출 비율=방출된 불소양/전체 불소양 $(1,450) \times 100$

\section{연마용 실리콘 포인트로 연마된 레진 시편의 불소 방출량 실험}

앞의 실험과 동일한 원료를 사용하여 실제 연마용 실리콘 포 인트를 제작하였다(Fig. 2). 제작된 실리콘 포인트의 크기는 헤 드부 지름은 $4.3 \mathrm{~mm}$ 이며 $9 \mathrm{~mm}$ 의 길이의 불꽃 모양으로 제작 하였다. 헤드부 중합 성형을 위해 헤드부 지름 $4.3 \mathrm{~mm}$ 이고 9 $\mathrm{mm}$ 의 길이의 불꽃 모양의 몰드(Weningtec, Jangsung, Korea)
를 제작하였고, 회전축인 mandrel (Mesetec, Gwangju, Korea) 은 실리콘 포인트 헤드 부분이 $4.3 \mathrm{~mm}$ 지름이며, shank의 길이 는 $20 \mathrm{~mm}$ 로 제작하여 진행하였다. $1,450 \mathrm{ppm}$ 의 불소가 혼합 된 원료와 mandrel을 포인트 타입의 몰드에 넣고 동일한 광경 화기로 헤드부 상하좌우를 각 25초간 광조사하여 실리콘 포인 트를 제작하였다. 대조군인 불소가 함유되지 않은 일반 실리콘 포인트는 불소 원료만을 제외하여 같은 방법과 재료를 이용하 여 제작하였다.

연마용 실리콘 포인트로 연마를 시행할 레진 시편은 불소가 함유되지 않은 레진(NT-FILL Composite resin A3; Denbio, Gwangju, Korea)을 이용하여 $15 \mathrm{~mm}$ 지름의 원형 디스크 타입 으로 제작하였다. 앞의 실험에 사용되었던 동일한 아크릴 몰드를 사용하였고 광경화기와 조사조건 등도 동일하게 적용하였다.

제작된 연마용 실리콘 포인트를 핸드피스(NSK EC, Kanuma, Japan)에 장착하고 컨트롤러(Marathon-3; SAEYANG, Daegu, Korea)를 사용하여 3,000 rpm의 속도로 레진 시편 표면을 각 5 초간 5회 고르게 연마하고, 레진 시편을 증류수로 약하게 세척 하였다(Table 2).

연마된 레진 시편위의 불소 방출량을 평가하기 위해 시편의 무게를 측정하고 지름 5곳을 측정하여 평균 지름을 계산하고, 시편의 중심부와 균일한 간격으로 떨어진 주변부 4 곳의 두께를 측정하여 평균 두께를 계산하여 표면적 $\left(\mathrm{cm}^{2}\right)$ 을 계산하였다. 10 $\mathrm{mL}$ 의 탈이온수(DIWater)가 담긴 플라스틱 용기에 시편을 각각 침지하고, $37^{\circ} \mathrm{C}$ 드라이오븐에 각 5 개의 시편씩 1 일(24시간), 3 일(72시간), 7일(168시간), 9일(216시간)을 보관 후 시편을 제 거하고, 피펫으로 검액 $1 \mathrm{~mL}$ 을 채취하여 탈이온수 $9 \mathrm{~mL}$ 를 더하
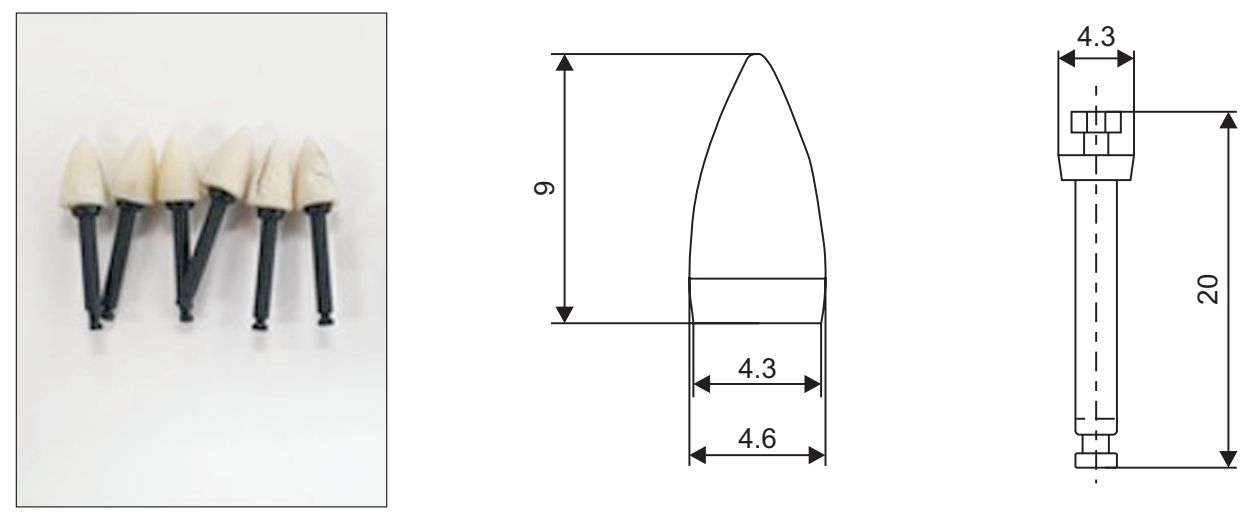

Fig. 2. Point type polishing kit and size (unit: $\mathrm{mm}$ ).

Table 2. Group explanation for fluoride releasement on the polished resin specimens by silicone point

\begin{tabular}{|c|c|c|c|c|}
\hline Number of specimens & $24 \mathrm{~h}$ & $72 \mathrm{~h}$ & $168 \mathrm{~h}$ & $216 \mathrm{~h}$ \\
\hline Polished resin specimens by conventional silicone point & 5 & 5 & 5 & 5 \\
\hline Polished resin specimens by silicone point with $1,450 \mathrm{ppm}$ fluoride ion & 5 & 5 & 5 & 5 \\
\hline
\end{tabular}


고 완전히 혼합하여 불소이온 측정 시험용액을 만든다. 시험용 액에 TISAB buffer solution $10 \mathrm{~mL}$ (TISAB II)을 첨가하고, 불 소미터(TiN-5101)를 이용하여 각각의 시험용액에 대한 불소농 도를 측정한다. 시험용액에서 측정한 값으로부터 검액의 불소 농도를 계산하여 불소 방출량을 아래 식과 같이 계산한다.

불소 방출량 $\left(\mu \mathrm{g} / \mathrm{cm}^{2}\right)=($ 검액의 불소농도 $[\mu \mathrm{g} / \mathrm{mL}] \times$ 검액의 양 $[10 \mathrm{~mL}]) /$ 표면적 $\left(\mathrm{cm}^{2}\right)$

불소 방출 비율=방출된 불소양/전체 불소양 $(1,450) \times 100$

\section{통계분석}

통계 분석을 위해 통계 프로그램(IBM SPSS Statistics ver. 25.0; IBM Corp., Armonk, NY, USA)을 이용하였고, KruskalWallis 분석을 시행하였고, 사후 분석을 위해 Bonferroni correction을 이용하였고, Mann-Whitney 분석을 시행하였다. 유 의확률은 0.05 이었고, bonferroni correction의 유의확률은 0.001 이었다.

\section{Results}

불소를 함유한 실리콘 포인트의 불소 방출량은 1 일차에는 평

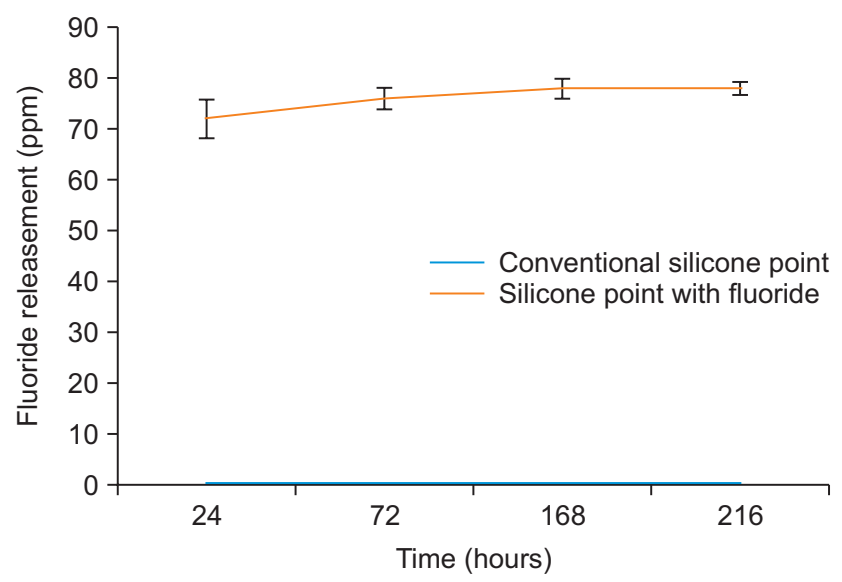

Fig. 3. Fluoride releasement amount of silicone point.
균 $71.68 \mathrm{ppm}$, 3일차에는 $75.52 \mathrm{ppm}$, 7일차에는 $77.50 \mathrm{ppm}$, 9일차에는 $77.58 \mathrm{ppm}$ 으로 측정되었고, 대조군인 불소를 함유 하지 않은 실리콘 포인트의 불소 방출량은 $0 \mathrm{ppm}$ 이었다. 1 일 차에 가장 많은 불소 방출량이 증가되었고 3일차에는 $5.36 \%$ 가 늘었으며 7일차에는 $2.62 \%, 9$ 일차에는 $0.10 \%$ 만 늘었다. 1,450 $\mathrm{ppm}$ 의 불소가 혼합된 원료를 실제 광중합 성형하였을 때 실제 불소 방출량은 9일차까지 투입량의 4.66\%-5.48\%인 것으로 측 정되었다. 불소가 함유되지 않은 시편은 1일에서 9일차까지 불 소가 전혀 방출되지 않았다(Fig. 3, Table 3). 이는 대조군과 비 교하여 불소를 함유한 실리콘 포인트의 불소 방출량은 통계적 유의성을 보였다. 하지만 방출기간 사이에는 통계적 유의성을 보이지 않았다.

불소를 함유한 실리콘 포인트로 연마된 일반 레진 시편의 불 소 방출량은 1 일차에는 평균 $7.98 \mathrm{ppm}, 3$ 일차에는 $8.48 \mathrm{ppm}$, 7일차에는 $8.80 \mathrm{ppm}$, 9일차에는 $8.75 \mathrm{ppm}$ 을 나타내었고, 일 반 실리콘 포인트로 연마된 레진 시편에서는 불소 방출을 보이 지 않았다. 1 일차에 가장 많은 불소 방출량이 증가되었고 3 일차 에는 $6.29 \%, 7$ 일차에는 $3.85 \%$ 의 방출 증가율을 나타내었다. 9 일차에는 오히려 7 일차에 비해 $0.59 \%$ 감소하였다. 이 결과 역 시 일반 실리콘 포인트와 불소를 함유한 실리콘 포인트 사이에 는 통계적 유의성을 보였으나, 불소를 함유한 실리콘 포인트를

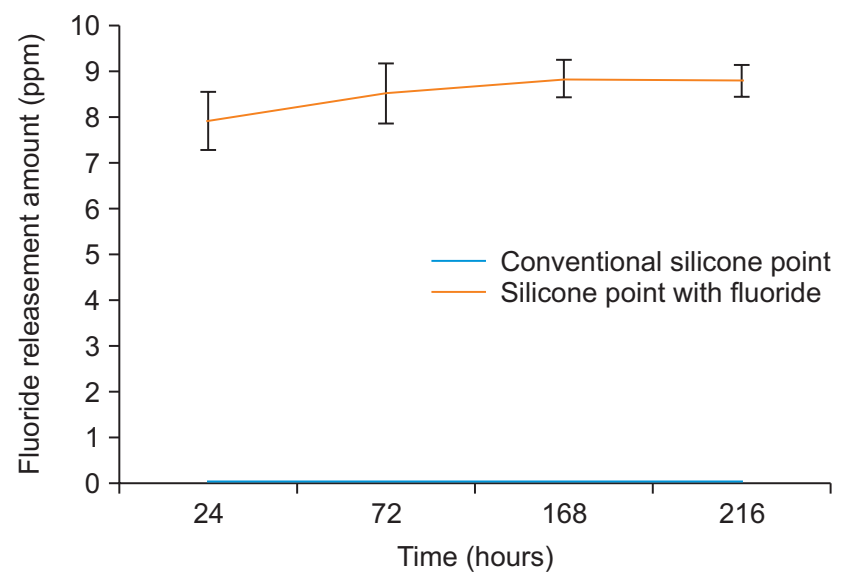

Fig. 4. Fluoride releasement amount of polished resin specimen by silicone point.

Table 3. fluoride releasement amount of the silicone point (unit: ppm)

\begin{tabular}{|c|c|c|c|c|}
\hline \multirow{2}{*}{ Group } & \multicolumn{4}{|c|}{ Time } \\
\hline & $24 \mathrm{~h}$ & $72 \mathrm{~h}$ & $168 \mathrm{~h}$ & $216 \mathrm{~h}$ \\
\hline Conventional silicone point & $0 \pm 0^{\mathrm{a}}$ & $0 \pm 0^{\mathrm{a}}$ & $0 \pm 0^{\mathrm{a}}$ & $0 \pm 0^{\mathrm{a}}$ \\
\hline Silicone point with $1,450 \mathrm{ppm}$ fluoride & $71.68 \pm 3.83^{\mathrm{b}}$ & $75.52 \pm 2.19^{\mathrm{b}}$ & $77.50 \pm 1.86^{\mathrm{b}}$ & $77.58 \pm 1.30^{\mathrm{b}}$ \\
\hline
\end{tabular}

Values are presented as mean \pm standard deviation.

${ }^{\mathrm{a}, \mathrm{b}}$ Other alphabets mean statistical significance. 
Table 4. fluoride releasement amount of the polished resin sepecimens by silicone point (unit: ppm)

\begin{tabular}{lcccc}
\hline \multirow{2}{*}{ Group } & \multicolumn{3}{c}{ Time } \\
\cline { 2 - 5 } & $\mathbf{2 4 h}$ & $\mathbf{7 2 ~ h}$ & $\mathbf{1 6 8} \mathbf{~ h}$ & $\mathbf{2 1 6} \mathbf{~ h}$ \\
\hline Conventional silicone point & $0 \pm 0^{\mathrm{a}}$ & $0 \pm 0^{\mathrm{a}}$ & $0 \pm 0^{\mathrm{a}}$ & $0 \pm 0^{\mathrm{a}}$ \\
Silicone point with 1,450 ppm fluoride & $7.98 \pm 0.62^{\mathrm{b}}$ & $8.48 \pm 0.65^{\mathrm{b}}$ & $8.80 \pm 0.41^{\mathrm{b}}$ & $8.75 \pm 0.35^{\mathrm{b}}$ \\
\hline
\end{tabular}

Values are presented as mean \pm standard deviation.

${ }^{\mathrm{a}, \mathrm{b}}$ Other alphabets mean statistical significance.

이용 시 그 방출 기간 사이에는 통계적 유의성을 보이지 않았다 (Fig. 4, Table 4).

이 두 가지의 실험을 토대로 실리콘 포인트 제작 시 1,450 $\mathrm{ppm}$ 의 불소이온을 첨가하였지만, 실리콘 포인트에서 방출된 불소는 시간에 따라 약 71-77 ppm 정도임을 알 수 있었다. 또 한 이 실리콘 포인트를 이용하여 일반 레진을 연마하였을 때, 연 마된 레진 시편에서는 시간에 따라 약 7-8 ppm 정도의 불소를 방출함을 보아 연마된 레진 시편에 흡착된 불소의 양을 알 수 있다.

$1,450 \mathrm{ppm}$ 의 불소가 혼합된 원료로 만들어진 실리콘 포인트 로 레진 시편을 연마하였을 때 1일차에서 9일차까지 레진 연마 면의 불소 방출량은 원료 혼합량(1,450 ppm) 기준으로 $0.55 \%$ $0.60 \%$, 실리콘 포인트의 불소 방출량은 $4.94 \%-5.35 \%$ 가 방출되 었다.

\section{Discussion}

1939년 Dean은 불소가 충치억제 효과가 있음을 발표한 이 후, 현재는 전세계적인 상수도 불소화 사업, 불소 치약, 불소 용 액 양치, 불소가 함유된 수복재료 등 우리의 생활에 불소를 다양 하게 이용하고 있다[9]. 불소(F)는 플루오르(fluorine)로 불리는 할로겐 원소의 일종으로 적량의 불소는 충치 예방에 효과가 있 는 것으로 알려져 있다. 본 연구는 치아우식 활성도가 높은 환자 에서 치료와 동시에 치아우식 예방 효과를 얻을 수 있는 방법을 제시하고자 하였으며, 다회용으로 사용되고 있는 치과용 연마 용 실리콘 포인트에 항균 효과를 기대할 수 있는지 검증하고자 하였다.

불소의 치아우식 예방 기전은 아직 정확히 알려져 있지 않지 만, 불소가 치아 형성기의 법랑질과 반응하면 불화 칼슘을 형성 하지 않고 법랑질 내에 불화인회석을 형성하게 되고, 이는 산에 대한 내성을 증가시키게 된다[10,11]. 또한 이러한 불소의 침착 은 건전한 치아 표면보다도 치아우식에 이환된 부위의 치아 표 면에서 더욱 잘 일어난다[12,13]. 즉, 치아우식 초기 부위에 불 소가 침착되어 불화인회석을 형성함으로서 효과적으로 치아우 식을 예방하는 역할을 한다[9,14]. 또한 불소는 $\mathrm{HF}$ 의 형태로 이 온이 방출되는데 이는 세포 내 산성도를 낮출 뿐만 아니라, 치아
우식균인 Streptococcus mutans 의 대사도 방해한다[15,16].

불소의 치아우식 예방 효과를 나타낼 수 있는 최소 농도에 대 한 기존 연구들을 참고할 때, in vitro 실험에서 $1 \mathrm{ppm}$ 정도의 불소농도가 세균의 산 형성 능력을 감소시킨다고 보고한 연구 가 있었고[17], 산 형성 세균의 성장 증식의 억제를 위해서는 적 어도 19 혹은 $20 \mathrm{ppm}$ 정도의 불소농도가 필요하다는 논문도 보고되었다. 혹은 불소농도뿐만 아니라 $\mathrm{pH}$ 가 영향을 미친다는 보고도 존재하였다[18-20]. Featherstone [21]은 in vitro 및 in vivo 연구에서 타액의 불소농도가 $0.1 \mathrm{ppm}$ 이상이면 우식 위험 도가 높은 사람들에게 항우식효과가 있다고 보고하였다.

본 연구 결과에서 불소의 방출 양상은 첫 24시간 동안 다량 의 불소가 유리되는 'burst out' 양상을 보이고 이후 방출량은 점차 감소하는데 이는 불소를 함유한 다른 수복재의 양상과 일 치한다[1]. 이에 대한 기전은 아직 명확하게 밝혀지지 않았지만 Kuhn과 Wilson [22]의 surface wash off 이론으로 설명될 수 있다. 연마용 실리콘 포인트는 수복재보다 다공성이 많기 때문 에 많은 양의 불소를 흡수하여 방출할 수 있다.

$1,450 \mathrm{ppm}$ 의 불소를 함유한 실리콘 포인트의 불소 방출량 은 1일차에는 $71.68 \mathrm{ppm}, 3$ 일차에는 $75.52 \mathrm{ppm}, 7$ 일차에는 $77.50 \mathrm{ppm}$, 9일차에는 $77.58 \mathrm{ppm}$ 으로 측정되었다. 기존의 치 아우식 예방 효과를 나타낼 수 있는 최소 농도에 대한 논문을 고 려해보면 충분히 치아우식이나 항균작용을 나타낼 수 있는 방 출량이다. 이는 세균의 산형성 능력을 감소시키고, 대사를 억제 하므로 항균 효과를 기대할 수 있다. 다회용으로 사용되고 있는 치과용 연마용 실리콘 포인트의 상황에서 이는 임상적으로 의 미있는 결과이다.

실리콘 포인트를 핸드피스에 장착하고 $3,000 \mathrm{rpm}$ 의 속도로 5초간 5회 고르게 연마된 레진 시편은 평균 7.98-8.80 ppm의 불소 방출량을 기록하였다. 이전 연구들을 참고하였을 때 적어 도 이는 치아우식 예방효과를 볼 수 있는 수치로 판단된다. 다만 이의 유지성에 대해서는 좀더 연구를 할 필요가 있으며 또한 사 용자(dentist)들의 실리콘 포인트를 사용할 때, 누르는 힘, 연마 횟수, 사용시간 등에 따라 연마면의 불소 방출량은 충분히 증감 될 수 있으므로 추가적인 연구가 필요하다.

평균적으로 실리콘 포인트로 연마된 일반 레진 시편의 불소 
방출량은 3일차 $6.29 \%, 7$ 일차까지 $3.85 \%$ 증가됨을 기록하였고 9일차에는 7일차와 비교하여 $0.59 \%$ 감소하였다. 현재 치아우식 예방 치료로 흔히 이용되고 있는 불소 바니시 치료를 참고하면, 불소 도포 후 식사나 칫솔질 등 물리, 화학적인 자극으로 인해 대부분 24 시간 이내에 제거되는 만큼, 불소 바니시의 초기 방출 능력이 중요한 평가 지표가 된다. 구강 내에 불소가 적용되었을 때 제거되는 과정을 발표한 Dawes와 Weatherellm [23]의 논 문을 보면, 불소치약이나 불소 함유 껌은 2 시간 이내에 제거되 었고, 불소젤이나 불소 양치액은 2 시간에서 24 시간 정도까지만 불소가 구강 내에 잔류한다고 보고하였다. 일반인들이 가정에 서 많이 사용하는 불소치약은 약 15\%-20\%의 항우식효과가 있 으며 최근 선진국에서 치아우식중의 급격한 감소 이유로 상수 도불소화와 함께 불소치약 사용이 중요한 역할을 하였다고 보 고 되고 있다[24]. 이를 볼 때 이번 연구에서의 불소 방출량은 치 아우식 예방 효과의 가능성을 기대할 수 있다.

본 연구에서는 불소를 치아에 직접 도포하는 방식이 아닌 심 미수복 시 사용되는 연마용 실리콘 포인트에 불소이온(F-)을 혼 합하였는데, 이때 불소 투입량 설정 시에는 다음과 같은 것을 고 려하였다. 최종 제품인 연마용 실리콘 포인트가 치약과는 달리 고체이며 사용부위도 극히 한정되어 있고 사용 중 발생되는 미 세분말도 3 way syringe 등에 의해 바로 고압 세척됨을 고려하 였으며 식품의약품안전처의 불소치약 허용기준치 $1,500 \mathrm{ppm}$ 을 감안하여 최대 $1,450 \mathrm{ppm}$ 까지만 함유시킴을 원칙으로 하였 다[25]. 일자(시간)별 불소 방출량 실험에 있어 그 해당 시기까 지 시편을 침지만 하고 별다른 외부 자극을 주지 않은 것은 각 실험군에 대한 순수 불소 방출량 확인이 제일 먼저 필요했기 때 문이다. 각 실험군의 순수 불소 방출량과 방출 성향을 확인함으 로써 차후 연구에서 좀 더 정확하고 다양한 조건으로 접근이 가 능할 것이다. 구강 내 자극 요소(음식, 칫솔질, 저작습관 등)를 고려하여 침지 외에 일정량의 세척과 자극 조건을 다양화하여 추가적인 연구가 필요할 것으로 생각된다.

\section{Conflicts of Interest}

The authors declare that they have no competing interests.

\section{ORCID}

In-Sun Jeong
https://orcid.org/0000-0003-0259-7333
Hong-Won Kang
https://orcid.org/0000-0003-0195-1396

Kwi-Dug Yun

https://orcid.org/0000-0002-2965-3967

\section{References}

1. Bae IH, Kim JM, Jeong TS, Kim S. Fluoride release and recharge of glass ionomer cements. J Korean Acad Pediatr Dent 2005;32:136-143.

2. Hicks MJ, Flaitz CM, Silverstone LM. Secondary caries formation in vitro around glass ionomer restorations. Quintessence Int 1986;17:527-532.

3. Park YJ, Yang HS. Synthesis of fluoride releasing resin and fluoride level changes of the tooth structure. J Korean Res Soc Dent Mater 1987;14:35-55.

4. Kim SY, Choi SC, Kim KC, Choi YC, Park JH. In vitro study of demineralization inhibition effect and fluoride uptake into adjacent teeth of light-cured fluoride-releasing restoratives. J Korean Acad Pediatr Dent 2010;37:288-297.

5. Featherstone JD. Prevention and reversal of dental caries: role of low level fluoride. Community Dent Oral Epidemiol 1999;27:31-40. doi: 10.1111/j.1600-0528.1999.tb01989.x.

6. Kim JS, Byon MJ, Nam YT, Kim JB, Jeong SH. In vitro fluoride release from five different fluoride varnishes. J Korean Acad Oral Health 2019;43:184-190. doi: 10.11149/ jkaoh.2019.43.4.184.

7. Beltrán-Aguilar ED, Goldstein JW, Lockwood SA. Fluoride varnishes. A review of their clinical use, cariostatic mechanism, efficacy and safety. J Am Dent Assoc 2000;131:589596. doi: 10.14219/jada.archive.2000.0232.

8. Marinho VC, Worthington HV, Walsh T, Clarkson JE. Fluoride varnishes for preventing dental caries in children and adolescents. Cochrane Database Syst Rev 2013;(7):CD002279. doi: 10.1002/14651858.CD002279. pub2.

9. Kim JW. Fluorine-releasing of dental restoration materials in which the fluorine is contained. J Korea Contents Assoc 2012;12:311-322. doi: 10.5392/JKCA.2012.12.05.311.

10. Lee YG. Determination of optimal fluoride concentration for the remineralization of incipient caries in vitro. Seoul: Korea Science and Engineering Foundtion; 2009 Apr. Report No.: TRKO201000013619. 5 p.

11. Smith DC. Composition and characteristics of glass ionomer cements. J Am Dent Assoc 1990;120:20-22. doi: 10.14219/jada.archive.1990.0002.

12. Aasenden R, Peebles TC. Effects of fluoride supplementation from birth on human deciduous and permanent teeth. Arch Oral Biol 1974;19:321-326. doi: 10.1016/00039969(74)90194-0.

13. Jang KT. A study on the antimicrobial effect of fluoridereleasing removable orthodontic appliances. J Korean Acad Pediatr Dent 1999;26:133-138.

14. Cho H, Lee KH, Kim DE. Effects of Nd:YAG laser irradiation 
and fluoride application on remineralization of the enamel. J Korean Acad Pediatr Dent 2004;31:381-390.

15. Seppä L, Forss H, Ogaard B. The effect of fluoride application on fluoride release and the antibacterial action of glass ionomers. J Dent Res 1993;72:1310-1314. doi: $10.1177 / 00220345930720090901$.

16. Jenkins GN. Review of fluoride research since 1959. Arch Oral Biol 1999;44:985-992. doi: 10.1016/s00039969(99)00110-7.

17. Kim MK, Lee KS. In vitro study on the fluoride release from glass ionomer cements and a fluoride-containing resin. Korean J Orthod 1998;28:399-407.

18. Lilienthal B. The effect of fluoride on acid formation by salivary sediment. J Dent Res 1956;35:197-204. doi: $10.1177 / 00220345560350020601$.

19. Jenkins GN. The effect of $\mathrm{pH}$ on the fluoride inhibition of salivary acid production. Arch Oral Biol 1959;1:33-41. doi: 10.1016/0003-9969(59)90019-6.

20. Thylstrup A, Fejerskov O. Textbook of clinical cariology. 2nd ed. Copenhagen: Munksgaard; 1994.

21. Featherstone JD. Delivery challenges for fluoride, chlorhexidine and xylitol. BMC Oral Health 2006;6(Suppl 1):S8. doi: 10.1186/1472-6831-6-S1-S8.

22. Kuhn AT, Wilson AD. The dissolution mechanisms of silicate and glass-ionomer dental cements. Biomaterials 1985;6:378-382. doi: 10.1016/0142-9612(85)90096-1.

23. Dawes C, Weatherell JA. Kinetics of fluoride in the oral fluids. J Dent Res 1990;69:638-644; discussion 682-683. doi: 10.1177/00220345900690S125.

24. Kim BI, Kwon HK. Salivary fluoride concentration after wearing acrylic removable appliance with glass ionomer cement specimen embedded. J Korean Acad Dent Health 1997;21:23-40.

25. Regulations for reviewing items permission reporting for Quasi drugs [Internet]. Sejong: Ministry of Government Legislation; 2017 [cited 2020 Jun 1]. Available from: http://www.law.go.kr/admRulLsInfoP. do?admRulSeq=2100000030205 